\title{
LECTURES' PERCEPTION TOWARD THE NEED OF ENGLISH \\ IN MANAGEMENT ECONOMICS DEPARTMENT OF PEKALONGAN UNIVERSITY
}

\section{Ida Ayu Panuntun, dan Rizka Hayati}

Pekalongan University

Email: ayyu idda@yahoo.com

\section{Info Artikel}

\section{Sejarah Artikel:}

Diterima 21Agustus 2018

Direvisi 6 November 2018

Disetujui 22 November 2018

\section{Keywords:}

Need Analisys, ESP of

Management Economics.

Lecturer's perception.

\begin{abstract}
This study aimed to describe the English needs of the Economics Management Study Program of Pekalongan University based on the perception of the English lecturers. The research design of this research was descriptive qualitative. The total sample used was 2 English lecturers in the Economics Management study program. The research instrument used was a questionnaire with a measurement scale in the form of numbers. The research data was described through needs, real conditions in the classroom, and the desire of the lecturer. The real conditions of learning in the classroom become a basic guideline for achieving the learning objectives in the target needs. These results were also adjusted to the wishes (Wants). Thus, it could be seen that according to the lecturers 'perception, English was an ability that had to be mastered in order to fulfill the students' self-need to understand the economic context in using English. Moreover, understanding and mastering the material supported students to compete in the world of work. From the lecturers' perspective, it was known that speaking ability was the most important ability to be owned by students, and the difficulties most often faced by students according to the lecturer was in listening skill.
\end{abstract}

\begin{abstract}
Abstrak
Penelitian ini bertujuan untuk menggambarkan kebutuhan Bahasa Inggris Universitas Pekalongan prodi Ekonomi Manajemen berdasarkan persepsi dosen Bahasa Inggris. Desain penelitian yang digunakan dalam penelitian ini adalah deskriptif kualitatif. Jumlah sampel pada penelitian ini adalah 2 dosen pengampu mata kuliah Bahasa Inggris pada prodi Ekonomi Manajemen. Instrumen penelitian yang digunakan adalah kuesioner dengan skala pengukuran dalam bentuk angka. Data penelitian ini dijelaskan melalui kebutuhan, kondisi nyata di dalam kelas, dan keinginan dosen. Kondisi nyata belajar di dalam kelas menjadi pedoman dasar untuk mencapai tujuan pembelajaran sesuai dengan target kebutuhan. Hasil ini juga disesuaikan dengan keinginan (Wants). Dengan demikian, hal ini bisa dilihat bahwa menurut persepsi dosen, Bahasa Inggris adalah kemampuan yang harus dikuasai oleh siswa dalam memehami Bahasa Inggris supaya dapat dipergunakan dalam konteks perekonomian. Terlebih pemahaman dan penguasaan Bahasa Inggris dimanfaatkan untuk berkompetesi dalam dunia kerja.Berdasarkan perspektif dosen, kemampuan berbicara adalah kemampuan yang paling penting untuk diuasai mahasiswa dan kesulitan yang paling sering dihadapi oleh siswa menurut dosen adalah keterampilan mendengar.
\end{abstract}


Panuntun, Ida Ayu., dan Hayati, Rizka

LECTURES' PERCEPTION TOWARD THE NEED OF ENGLISH IN MANAGEMENT ...

REFLEKSI EDUKATIKA : Jurnal Ilmiah Kependidikan, Nomor 9, Volume 1, Desember 2018, hlm. 1-5

\section{INTRODUCTION}

The role of language in communication is very important. Its role is always integrated to the other fields. Each country has used language to communicate each other. It can be used in the personal communication or community one. Language helps people to share their idea. And, the need of mastery the language has been a government's special duty in each country, such as Indonesia.

Indonesia is a country with different variety of language and culture.Its different variety not become a problem among the individuals. Why? Since Indonesian people have Indonesian language as an unity language.

Beside Indonesian language, Indonesia also uses English as a foreign language. And in Indonesia, English will be learn from the elementary level to the university one.

In the university level, English is a subject which has been taken by all students from every faculty such as in Pekalongan University. One of the departments in Pekalongan University is Management Economics study program.

In Management Economics department, Bahasa Inggris (the name of the English subject) has two levels. Those are Bahasa Inggris I and Bahasa Inggris II. Both of them have been taken by the students. All this time, the teaching learning process of Bahasa Inggris I and II have been running well. But, when we looked at the situation of the class was not comfortable enough. It could be seen from the students' appereance in following of the process. Manystudents were not enthusiastic in that subject.And it happened as a phenomenon which often occurs in Economic faculty, especially Management department. Most of the materials which had been delivered in this departement focussed in General English.

General English means that all materials only focsuses on the use of correct structure in either written form or spoken one. Most of the texts used in this learning was still in general. There was not related to the context of Economics. From those, the students only got the understanding of the material with mastering English vocabularies in daily life without any relation to the terms of Economics.

English which is used in special department, such as Management Economics study program has very complicated terms. It can be said that English for specific purpose has difficult terms than English used in general. It means that actually those terms are related to the real needs and are made to prepare the students in their work later.

Based on the background of the study above, this findinghas been used as areason for the reseachers to give further description about the need of English for Management Economics department of Pekalongan University.

The statement of the problem of this research is "How is the lecturers' perception toward the need of English in Management Economics department of Pekalongan University?"

According to Richards (2001: 51), need analysis is procedures which will be done to know the student's need in the teaching learning process. West (1994) stated that language needs analysis was essentially a pragmatic activity focused on specific situations, although grounded in general theories, such as the nature of language and curriculum. Moreover Nunan (1989: 75) states that need analysis is a procedure in collecting the information of student's need in learning. Based on the statements above, it can be concluded that need analysis is a step or procedure which has to be done to collect the data about the students' need in the teaching learning process. Dudley-Evans and St John (1998) stated that "need analysis was the process of establishing what and how of a course".

Robinson (1991) suggested that needs analysis study should be repeated so that it could be built into the formative process. English for Specific Purposes (ESP) is an English subject which is taught for special purpose. According to Hutchinson dan Walters (1987), English For Specific Purposes (ESP) is an approach of language teaching in which the content and method are based on the students' reason to study. Based on that statement, it can be concluded that learning ESP is special. The English materials which have been taught is made to be appropriate with each need of the department. For example, the subject of ESP in Management department, Bahasa Inggris which should be delivered in relation to the Management Economics field. Beside that, Susanto (2013: 266-267) states that choosing the method which will be used by the teachers in their teaching learning process, should be creative.

The researchers used the basic theory of Richards in constructing the instrument. Richards (2001: 80-88) describes analyze the need has to be based on the three dimension. Those three 
dimension are be stated here: 1) Overview from the perspective of the need and the difficulties that often occurs; 2) Overview from the perspective of the topic needed; 3) Overview from the component of the communicative competence

From the third point above, it can be explained clearly that communicative competence divided in the skill of (listening, speaking, reading and writing) and the structure competence which consists of grammar and vocabulary).

Explaining about the learning objective, the researcher still used Richards' theory. Based on the statement of Richards' (2001:112), learning objective can be seen from some perspectives. Those are: 1) Objective usually in the form of general statement; 2) Generally that statement will be a motivation to reach the certain purpose; 3) A program will be efective if it can show a clear objective

The three perspective should be integrated to each other to formulate a clear objective to make a design of syllabus. Those objectives are used to arrange the material. The following is the steps in arranging the material: 1) Observing that Standard Competence should be in line to the Basic Competence; 2) Developing material; 3) Organize the learning activity; 4) Determining indicators; 5) Determining evaluation; 6) Determining the time; 7) Mentioning the source.

\section{RESEARCH METHOD}

This research was a qualitative research in which the subject of this research was 2lecturers who taught English in Management Economics department of Pekalongan University.The researchers used questionnaire with the scale of number in collecting the data. The questionnaire was taken from Rosdiana (2015). In this questionaire, the researchers focussed on communication activity which are needed, language structured used and students' difficulties and the difficulties which often occur. The scale of questionnaire: 0,1- 1 (Not Useful), 1,01 - 2 (less useful), 2,01 -3 (quite useful), 3,01 -4 (useful), 4,01 -5 (very useful). In analyzing the data, the reseachers did several steps. First, analyzing the data quantitatively. Second, analyzing the data qualitatively. The steps were: 1) Tabulating the data;2) Identifying the score of tabulated data; 3) Classifying the score into its categories; 4) Describing the categories based on the score from the scale; 5) Interpreting the need of English for Management Economics department.

After conducting the research, the reseachers got the data from the lectures as the sample. Based on the data, it could be seen that the subject of English for the Managemnet Economics study program at Pekalongan University was very important to be mastered. It was related to the learning objectives of Management department. From the questionnaire which was given to the lecturers, the reseachers described the real condition of the students'need in learning English based on the lecturers' perception. The research data was described in English target (necessities) and wants.

\section{FINDING AND DISCUSSION}

Based on the target of the Management Economics study program of Pekalongan University, learning English is hoped (1) to make the students understandand and able to use the specific English terms about Management Economics, and (2) the Management Economics students are able to compete in looking for a job.

English was the subject that must be taken for Management Economics students. The real condition of the English students from Management department got the general materials of English. It was not interesting, so there was no motivation from the students. Moreover, the learning texts were only based on reading in general. The texts that often given was not too correlated with the terms of Management Economics. It was still general, lack of context of Management Economics. Most of the time they spent their learning time to study reading in class with the monotonous technique. Reading with monotonous technique here was giving the text and asked the students to answer the questions. There was not a challenging technique for the Management students who had different field with the English in general. Moreover, there was no task or assignment which asked the sudents to practice their English skill, such as speaking with the other people.

Wants was all about the needs which the English lecturers hoped. These wants could be seen from the data in the questionnaire which asked the lecturers about what the Management students needed. The following table shown that data. 
Panuntun, Ida Ayu., dan Hayati, Rizka

LECTURES' PERCEPTION TOWARD THE NEED OF ENGLISH IN MANAGEMENT ...

REFLEKSI EDUKATIKA : Jurnal Ilmiah Kependidikan, Nomor 9, Volume 1, Desember 2018, hlm. 1-5

Table 1. The Material for Management Economic Study Program

\begin{tabular}{|c|l|c|c|}
\hline No. & \multicolumn{1}{|c|}{ Aspect } & Mean & Criteria \\
\hline 1. & Pronunciation & 4 & Useful \\
\hline 2. & Listening Comprehension & 3.5 & Useful \\
\hline 3. & Giving Presentation & 5 & Very Useful \\
\hline 4. & Communicating effectively with peers & 5 & Very Useful \\
\hline 5. & Essay writing & 4.5 & Very Useful \\
\hline 6. & Describing object & 4.5 & Very Useful \\
\hline 7. & Writing introduction and conclusion & 4.5 & Very Useful \\
\hline 8. & Writing references and quotations & 4.5 & Very Useful \\
\hline 9. & Knowledge of vocabulary & 4.5 & Very Useful \\
\hline 10. & Reading quickly & 4.5 & Very Useful \\
\hline 11. & Reading critically & 4.5 & Very Useful \\
\hline 12. & Summarizing material & 4.5 & Very Useful \\
\hline 13. & General reading comprehension & 4 & Useful \\
\hline
\end{tabular}

All materials above got the score of (4 to 4.5) with predicate Useful to Very Useful. It meant that those materials and skills were so important to be practiced. Those could be used to make further understanding of combined skills.
On the other hand, the following data was taken from the lecturers' questionnaire about the communicative competence which consisted of speaking, listening, writing and reading

Table 2. The Mean Score of Each Skill as the Need of English

\begin{tabular}{|c|l|c|c|}
\hline No. & \multicolumn{1}{|c|}{ Skill } & Mean Score & Criteria \\
\hline 1. & Speaking & 4.64 & Very useful \\
\hline 2. & Listening & 4.5 & Very useful \\
\hline 3. & Writing & 4.45 & Very useful \\
\hline 4. & Reading & 4.42 & Very useful \\
\hline
\end{tabular}

Based on the table above, it could be seen that speaking skill had the highest score than others. Its highest score means that the need of speaking skill was more than the others. The next rank was listening, writing and reading. As the skill which the highest score, speaking should be mastered well since it was as a main priority. It can be interpreted that speaking is the activity which commonly used in the class. In teaching learning process of English, asked more students to be active in speaking. Beside this, the fluency in speaking can also be used when the students have to face the interview in getting a job and communicate with others. So, it can be concluded that all skills with their criteria of very useful should be mastered by the students.

Another finding about the difficulty faced by the students was as follows. The table of the mean score of the the difficulties faced by the students.

Table 3. The Frequent Difficulties Faced by the Students

\begin{tabular}{|c|l|c|c|}
\hline No. & \multicolumn{1}{|c|}{ Skill } & Mean Score & Criteria \\
\hline 1. & Speaking & 3 & Very Often \\
\hline 2. & Listening & 3.5 & Very Often \\
\hline 3. & Writing & 2.5 & Sometimes \\
\hline 4. & Reading & 2.5 & Sometimes \\
\hline
\end{tabular}

Based on the table above, speaking skill and listening were very often faced by the students. But, listening skill had the highest score than others. All this time, listening skill were less in practice so the students felt that it was so difficult. It means that listening skill should have had so many practices. This can be practiced using language laboratory as the facility or using other media that make the stusents interested and want to learn more.

\section{CONCLUSION}

The result of the research based on the lecturers perspectives, (1) the needs of English 
for the Management Economics department of Pekalongan University consists of all speaking, listening, reading and writing. All of them have to be mastered to reach the objective of learning English. The most important skill to be mastered based on lecturer's perspective is speaking skill because it has so many role in learning process in the class and in getting a job. (2) The difficulty which often faced by the students in learning English is listening skil. It means that lecturers need to focus more on teaching listening to the students.

The suggestions that can be offered are in the teaching learning process of English in Management Economics department should cover all skills, especially for speaking. Speaking which is measured as the activity with more role, should have require more time to practice. Beside that, in solving the difficulty of listening, the lecturers should give many practices with the appropriate and interesting media.

\section{REFERENCES}

Alfiana, Rizky dkk. 2017. Analisis Kegiatan Ekstrakurikuler Membatik terhadap Kemampuan Membatik Seni Rupa Siswa Sekolah Dasar di Desa Mantingan, Kecamatan Jaken, Kabupaten Pati. Refleksi Edukatika : Jurnal Ilmiah Kependidikan 8 (1), hlm: 43-47.

Arikunto, S. 2008. Evaluasi Program Pendidikan. Edisi ke 2. Jakarta: Bumi Aksara.

Bharati, Dwi Anggani Linggar. 2009. Teachers Professional Development through an Observation in Immersion Classes Based on the Documents and Teaching and Learning Processes. Malang: TEFLIN.

Cohen, Louis. 2007. Research Method in Education. New York : Routladge Taylor and Francis Group.

Gunnarsson, Britt-Louise. 2001. "Swedish, English* French or German." The dominance of English as a language of science: Effects on other languages and language communities 84 (2001): 287. in Vahed (2017) The Analysis of Faculty Needs to English for Academic Purposes in a Middle-Eastern Context.
Hutchinson and Waters'. 1987. English for Specific Purposes in Hermawati, Dyah Aju. Analisis Kebutuhan (Need Analysis) untuk Pembelajaran Bahasa Inggris Khusus (ESP) pada Kelas Manajemen Agroindustri Politeknik Negeri Jember.

Jordan, R. R. 1997. English for Acdemic Purposes in : A Guide and Resources Book. For Teachers. In Hermawati, Dyah Aju. Analisis Kebutuhan (Need Analysis) untuk Pembelajaran Bahasa Inggris Khusus (ESP) pada Kelas Manajemen Agroindustri Politeknik Negeri Jember.

Kayl, H. 2008. Developing ESL curriculum Based on Need and Situation in Analysis. A Case Study. Journal of Language and Linguistic Studies, 4 (1), pp 29-49.

Nunan. 1988. Syllabus Design in Puspitasari. English for Computer Science : Sebuah Analisis Kebutuhan Bahasa Inggris pada Mahasiswa Teknik Informatika.

Nunan, David. 2008. Research Method In In Language Learning. Cambridge. Cambridge University Press.

Richard. 2001. Curriculum Development in Language Teaching in Puspitasari. English for Computer Science : sebuah Analisis Kebutuhan Bahasa Inggris pada Mahasiswa Teknik Informatika.

Rosdiana, Ihda. 2015. Integrating Task Based Syllabus and Text Based Syllabus for Students of Politeknik Keselamatan Transportasi Jalan Tegal. Tegal: UPS.

Sugiono. 2009. Metode Penelitian Pendidikan : Pendekatan Kuantitatif, Kualitatif, dan $R n D$. Bandung : Alfabeta. 